\title{
A Case of Dengue Fever Complicated with Trombophlebitis in a Child
}

\section{Tromboflebit ile Komplike Olan Çocuk Dengue Ateşi Olgusu}

\author{
Deniz Özbay', Manolya Kara², Deniz Tuğcu³, Selda Hançerli Törün², Murat Sütçü, Emine Çalışkan5, \\ Nuran Salman², Ayper Somer ${ }^{2}$ \\ ${ }^{1}$ Department of Pediatrics, Istanbul University School of Istanbul Medicine, Istanbul, Turkey \\ ${ }^{2}$ Department of Pediatric Infectious Diseases, Istanbul University School of Istanbul Medicine, Istanbul, Turkey \\ ${ }^{3}$ Department of Pediatric Hematology, Istanbul University School of Istanbul Medicine, Istanbul, Turkey \\ ${ }^{4}$ Clinic of Pediatric Infectious Diseases, Konya Training and Research Hospital, Konya, Turkey \\ ${ }^{5}$ Clinic of Pediatric Radiology, Seyhan State Hospital, Adana, Turkey
}

Cite this article as: Özbay D, Kara M, Tuğcu D, Hançerli Törün S, Sütçü M, Çalışkan E, et al. A case of dengue fever complicated with trombophlebitis in a child. J Pediatr Inf 2019;13(1):e28-e31

\begin{abstract}
Dengue fever is a disease characterized by flu like symptoms which is endemic in tropic and subtropic regions. Dengue virus is from Filavivirus family. Dengue fever is rarely seen in our country. Hemorrhagic and thrombotic complications can be observed during the course of the disease. Herein we present a child case of Dengue fever diagnosed in our country who was complicated with thrombophlebitis. A previously healthy 16-year old boy was presented with headache, malaise and fever lasting for six days. He had returned from Philippines a week ago where he had stayed for a month. On physical examination, he was dehydrated with fever of $39.3^{\circ} \mathrm{C}$. His heart rate was $109 / \mathrm{min}$, respiratory rate was $28 / \mathrm{min}$, blood pressure was $132 / 78 \mathrm{mmHg}$, oxygen saturation was \%96 (room air) and capillary refill time was 5 seconds. His oral mucosa was dry and turgor was decreased. He had generalized erythematous rash, muscle pain and $2 \mathrm{~cm}$ splenomegaly. Laboratory examination revealed polycythemia and thrombocytopenia. He was hospitalized and intravenous hydration was initiated because of severe dehydratation and hemoconcentration. His history revealed that his roommate in Philippines was diagnosed as Dengue fever, recently. Pain and limitation of movement on left antecubital region developped on follow-up. Peripheral pulses could be palpated on both distal extremities and there was no difference of heat. Superficial doppler ultrasonography revealed echogenic thrombus extending from cephalic vein to wrist, and basilic vein to axillary region without recanalization. He was started on enoxa-
\end{abstract}

Öz

Dengue ateşi, tropikal ve subtropikal bölgelerde endemik olarak görülen, şiddetli grip benzeri semptomlara neden olan bir hastalıktır. Etkeni Filavivirus ailesinden Dengue virüsüdür. Dengue ateşi ülkemizde oldukça nadirdir. Hastalığın seyri sırasında hemorajik ve trombotik komplikasyonlar gözlenebilmektedir. Burada ülkemizde tanı alan tromboflebit ile komplike olmuş çocuk Dengue ateşi olgusu sunulacaktır. Öncesinde bilinen hastalığı olmayan 16 yaşında erkek hasta altı gündür süren ateş, baş ağrısı ve halsizlik şikayetleri ile başvurdu. Hasta iki gün önce bir ay süre ile ikamet ettiği Filipinler'den Türkiye'ye geri dönmüştü. Hastanın başvurusunda vücut Isısı $39.3^{\circ} \mathrm{C}$ idi, halsiz ve dehidrate görünümde idi. Kalp tepe atımı 109/dakika, dakika solunum sayısı 28, kan basıncı 132/78 $\mathrm{mmHg}$, oksijen satürasyonu oda havasında \%96, kapiller dolum zamanı 5 saniye idi. Oral mukozası kuru olan hastanın turgoru azalmıştı. Cildinde eritematöz döküntü ile tüm vücutta yaygın hassasiyeti mevcuttu. Dalak kot altı $2 \mathrm{~cm}$ ele gelmekteydi. Laboratuvar incelemesinde polisitemi ve trombositopeni mevcuttu. Belirgin dehidratasyon ve hemokonsantrasyonu mevcut olan hasta servise yatırılarak intravenöz (IV) hidrasyon tedavisi ile izleme alındı. Hastanın öyküsünden Filipinler'de birlikte kaldığı arkadaşının Dengue ateşi tanısı aldığı öğrenildi. İzleminde sol kol antekübital alanda ağrı ve hareket kısıtlılığı gelişti. Distalde periferik nabızları palpe edilebilen ve ekstremiteler arası ısı farkı gözlenmeyen hastanın çekilen yüzeyel Doppler ultrasonografisinde sefalik venden ön kolda bilek düzeyine kadar ve bazilik venden sol aksiller seviyeye ka-

\author{
Correspondence Address / Yazışma Adresi \\ Manolya Kara \\ İstanbul Üniversitesi İstanbul Tıp Fakültesi, \\ Çocuk Enfeksiyon Hastalıkları Bilim Dalı, \\ İstanbul-Türkiye \\ E-mail: manolya_kara@yahoo.com
}

@Copyright 2019 by Pediatric Infectious Diseases and Immunization Society. Available online at www.cocukenfeksiyon.org 
parin treatment. Serum Dengue fever IgM and IgG were reported as positive and he was discharged with recovery one week after hospitalization. Dengue fever should be considered as differential diagnosis of patients with flulike symptoms who had travel history to endemic countries. Hemorrhagic complications and hemorrhagic shock syndrome which are frequently seen in patients with Dengue fever can cause mortality. In addition, superficial and deep vein thrombosis can be observed in severely dehydrated patients with Dengue fever. These patients should be carefully observed for possible thromboembolic complications.

Keywords: Dengue fever, child, thrombophlebitis

\section{Introduction}

Dengue fever is a viral disease that is endemic in tropical and subtropical regions around the world, causing severe influenza-like symptoms. The causative agent is the Dengue virus from the Filavivirus family. According to the World Health Organization, approximately 500.000 of patients diagnosed with Dengue fever are hospitalized and approximately $2.5 \%$ of them die (1). The Dengue fever is seen in the Eastern Mediterranean, Africa, India and the Far East as well as in the Hawaiian and Caribbean islands, partly in the southern states of the United States and Australia. There are Dengue virus 1 and 2 serotypes in Turkey's neighboring Middle Eastern countries (2).

The increase in international commercial and leisure travel in our country together with the whole world has caused the endemic diseases to spread to different geographies. Dengue fever cases are not common in our country, but there are cases reported in the literature (3). It is known that these cases are not infected in the country and they are from abroad. There is a risk for passengers traveling to areas where the virus is endemic. Likewise, those who travel to our country from any of these regions can be effective in spreading the disease.

Dengue fever patients may present with many complications and thrombophlebitis is one of those. As a result of severe dehydration in these patients; due to increased vascular permeability and fever, hemoconcentration is common. In addition to these factors, protein $\mathrm{C}$ and $\mathrm{S}$ depletion and decreased plasma activity in the course of Dengue fever have also been reported (4). The combination of all these factors results in thrombosis and risk of secondary thrombophlebitis in patients with Dengue's fever.

16-year-old case diagnosed with Dengue fever who was diagnosed and complicated with thrombophlebitis in Turkey after travel abroad will be presented here. dar uzanan, rekanalizasyonun olmadığı ekojen trombüs izlendi. Hastaya enoksaparin tedavisi başlandı. Dengue ateşi IgM ve IgG testleri pozitif olarak sonuçlanan hasta yatışından bir hafta sonra şifa ile taburcu edildi. Endemik bölgelere seyahat öyküsü olan grip benzeri semptomlarla başvuran hastalarda Dengue ateşi ayırıcı tanıda düşünülmelidir. Dengue ateşli hastalarda sık görülen ve mortalitenin sık bir sebebi olan hemorajik komplikasyonlar ve hemorajik şok sendromuna karşı dikkatli olunmalıdır. Bununla beraber belirgin dehidrate Dengue ateşi hastalarında yüzeyel ve derin ven trombozları ile karşılaşılabileceği akılda bulundurulmalı ve hastalar tromboembolik komplikasyonlar açısından mutlaka değerlendirilmelidir.

Anahtar Kelimeler: Dengue ateşi, çocuk, tromboflebit

\section{Case Report}

A 16-year-old male patient with no known chronic disease presented with fever, headache and fatigue for six days. The patient had returned from Philippines where he resided for 1 month to Turkey two days ago. His body temperature was $39.3^{\circ} \mathrm{C}$, he was fatigued and dehydrated at admission. His oral mucosa was dry, and his turgor was decreased. He had erythematous rash which was concentrated in the acral regions that faded with thouch and widespread sensitivity in the whole body. His heart rate was $109 / \mathrm{min}$, respiratory rate was $28 / \mathrm{min}$, blood pressure was $132 / 78 \mathrm{mmHg}$, oxygen saturation was $96 \%$ in room air and capillary filling time was $5 \mathrm{sec}$. The spleen was palpated $2 \mathrm{~cm}$ below the rib margin. The patient had no hepatomegaly and his other system examinations were normal. Electrocardiography revealed sinus tachycardia.

Laboratory analysis revealed hemoglobin, $18.6 \mathrm{~g} / \mathrm{dL}$; hematocrit: $53 \%$; white blood cell count: $3890 / \mathrm{mm}^{3}$ (lymphocyte: $1600 / \mathrm{mm}^{3}$, neutrophil: $1400 / \mathrm{mm}^{3}$ ); platelet: $75.700 /$ $\mathrm{mm}^{3}$. No atypical cell was detected in peripheral smear and it was compatible with thrombocytopenia. Initial biochemical study revealed alanine aminotransferase (ALT): $76 \mathrm{U} / \mathrm{L}$, aspartate aminotransferase (AST): $47 \mathrm{U} / \mathrm{L}$ lactate dehydrogenase (LDH): $466 \mathrm{U} / \mathrm{L}$, creatinine: $0.9 \mathrm{mg} / \mathrm{dL}$ urea: $23 \mathrm{mg} / \mathrm{dL}$.

In the patient's history, it was learned that his friend whom he stayed with in the Philippines was diagnosed with Dengue's fever. The patient who had significant dehydration, thrombocytopenia and hemoconcentration was admitted to the inpatient service to be followed up with intravenous hydration therapy. As recommended for the patients in the vascular plasma leakage stage of Dengue fever, the hydration of the patient who had $25 \%$ hematocrit elevation was performed as $4 \mathrm{cc} / \mathrm{kg}$ per hour with isotonic fluid. Intravenous hydration of the patient at the end of 6 hours was replaced with solution containing $5 \%$ dextrose, $0.45 \% \mathrm{NaCl}\left(1500 \mathrm{cc} / \mathrm{m}^{2} /\right.$ day $)$ to meet 
the need for maintenance fluid. In the following days, since the patient's oral intake increased and his general condition improved, his intravenous hydration was gradually reduced and stopped.

On the $3^{\text {rd }}$ day of hospitalization, since the general condition of the patient was still poor and the fever continued septically, hemoculture and urine cultures were taken and piperacillin-tazobactam was started with the preliminary diagnosis of bacteremia. In abdominal ultrasonography, the spleen height increased up to $112 \mathrm{~mm}$, liver size increased up to $170 \mathrm{~mm}$, and bilateral renal parenchymal echogenicity was increased to grade 1.

In the follow-up of the patient, pain and movement limitation were observed in the antecubital area of the left arm. Peripheral pulses were palpable at the distal and no difference in temperature between the extremities was observed. In the superficial Doppler ultrasonography of the patient, an echogenic thrombus without recanalization extending from left cephalic vein to the wrist and from left basilic vein to the axillary region was observed. According to the family history of the patient, his uncle, who is over 45 years old, has a history of myocardial infarction and his father's uncle has a history of cerebral thrombosis after 55 -year-old. The factors involved in the coagulation pathways of the plasma were evaluated in the coagulation panel of the patient, who was examined for the conditions that caused hypercoagulability. The laboratory results were as follows: D-dimer (quantitative): $1169.98, \mathrm{~g} / \mathrm{L}(<550)$, protein S: 10.3\% (59-130\%), protein C: 112.4\% (70-140\%), APcR: 0.37 (0.691.6), anti-thrombin III: > 125.1 (75-125), factor 7: 120.8 (70-120), factor 8: > 150.3 (70-150), factor 9: > 129.5 (70-120), factor 12: 103.8 (70-150), von Willebrand factor antigen: 296.3 (50-160). [0105] vWF ristocetin cofactor: 222.7 (50-150).

The patient was diagnosed with superficial vein thrombosis. Despite extremity elevation and hydration treatment, no regression was observed in thrombosis. He was started on enoxaparin ( $1 \mathrm{mg} / \mathrm{kg} / \mathrm{dose}, 2$ doses of subcutaneous) treatment. This treatment was titrated according to the patient's anti-F10a level and continued until thrombosis resolution.

During the follow-up period, the fever which increased with shaking at nights continued for 1 week and the platelet and leucocyte levels of the patient became normal in time. Urine and hemocultures remained sterile and antibiotherapy was discontinued at the end of the first week. Dengue fever lgM and IgG tests that were studied from the blood samples sent to Istanbul Public Health Directorate were positive and the patient was discharged to be in control.

\section{Discussion}

The first Dengue fever in the literature was found about 200 years ago and in the 1940s, it was detected that the disease was a virus infection (5). Population mobility, which increased and continued during World War II and in the following period, started the spread of the virus which has continued to this day. Approximately 390 million people are estimated to be infected with Dengue's fever virus every year and about 500.000 of them require medical treatment (1).

Dengue fever remains its clinical importance as a tropical fever, as patients can be lost due to severe dehydration, hypovolemic shock, acute gastrointestinal bleeding, acute tubular necrosis or hypercoagulability. Its causative agent is Dengue virus from the Flavivirus family and has four different serotypes; DENV-1, DENV-2, DENV-3 and DENV-4. The Aedes (Stegomyia type) is transmitted to humans through flies (5).

It should be kept in mind that we may encounter diseases which are secondary to unseen factors in our country with the increase in the travels due to work, education or holidays all over the world. Although the cases diagnosed in our country are thought to be exposed to transmission abroad, the virus has been shown to exist in our country with the current importable cases. The areas where the disease is endemic are limited to the living areas of the Aedes-type flies with their specific vector. Although these species live in tropical and subtropical regions, according to the risk mapping of the European Center for Disease Protection and Control (ECDC) in terms of climate, humidity and elevation criteria, it has been shown that Aedes albopictus may be found in our country (3). This may be a sign that we can see not only importing cases, but also domestic infected patients in the coming years.

In the treatment of Dengue fever, provided that the appropriate plasma volume is maintained mortality rate of the disease is less than 1\% (6). It is understood that the most important point in the treatment of Dengue fever is to supply necessary hydration. In the guidelines prepared for this purpose, the importance of the calculation of 48-hour hydration support, the calculation of the maintenance fluid and deficits treatment, and calculating the fluid need dynamically according to the patient's clinical status were emphasized. While providing hydration support, it is important to monitor the vital signs, peripheral circulation, hematocrit and platelet values, daily urine output, renal and liver functions and coagulation parameters. In our case whose hematocrit was $54 \%$ at admission, hemoconcentration was improved after hydration.

Dengue fever cases frequently present with hemorrhagic complications, although rare, complications such as deep vein thrombosis or arterial thrombosis may occur in these patients (4). In Dengue fever, thrombotic complications may be due to hemoconcentration secondary to dehydration in the early period and may also be observed in later stages due to changes in the levels of coagulation factors. Gonçalves da Costa et al. have observed in a study conducted with Dengue fever patients diagnosed in Brazil that there were throm- 
botic complications in $5.4 \%$ of these patients (4). Wils et al. showed in a study on 167 Vietnamese children with Dengue fever syndrome developed that protein $\mathrm{C}$, protein $\mathrm{S}$ and antithrombin III levels showed significant decreases even though there were minor increases in prothrombin time and partial thromboplastin times but these levels decreased more as the shock clinic progressed (7). In our patient, there was a hemoconversion that increased by $25 \%$ in hematocrit. However, protein $\mathrm{S}$ levels were significantly decreased, Factor VIII levels increased and the APCR ratio, which is an indicator of activated protein $C$ resistance, was found to be low as an indicator of increased resistance. However, the $\mathrm{d}$-dimer value was found to be increased in the patient, supporting venous thrombosis. In blood coagulation factors, heights, which indicate hypercoagulability, were determined.

The etiology of hemorrhagic complications seen in Dengue fever includes the decrease in the number and function of platelets, increased vascular permeability, increased blood levels of anti-coagulant factors such as tissue plasminogen activator and thrombomodulin, and the reaction of antibodies with blood endothelial and blood coagulation factors $(9,10)$.

Among the factors that increase the risk of thrombosis and that are rare but seen in our patient; elevated levels of plasminogen activator inhibitor, activated complement system, high level cytokines and fibrinolysis may be shown. Although decreased protein $C$, $S$ and antithrombin III levels were seen in our patient as well as other cases, their relationship with clinical thrombosis was not proven. Disseminated intravascular coagulation is a complication that can be seen in severe cases of Dengue fever, but not associated with thrombosis of large vessels $(9,11)$.

Other complications that may occur in a patient suffering from Dengue's fever include a history of shock caused by high fever and hepatomegaly, hemorrhagic complications, ascites and pleural effusion related with increased capillary permeability and hemoconcentration due to reduction in plasma volume (12).

Liver dysfunction in approximately $1 / 3$ of patients diagnosed with Dengue fever manifests itself in days 2-3 following the onset of the disease. Transaminases increase up to two or three times, and hepatomegaly is detected in patients. Severe myositis also contributes to high aspartate aminotransferase. Fulminant hepatic insufficiency can be seen following hepatic necrosis, accompanied by shock and disseminated intravascular coagulation. Acalculous cholecystitis, Reye's syndrome, acute parotitis and diarrhea are rare, but can be seen in the course of Dengue's fever (12). In our patient, the transaminase levels were slightly high at the time of diagnosis (ALT: $76 \mathrm{U} / \mathrm{L}$, AST: $47 \mathrm{U} / \mathrm{L}$ ) and these values increased even further (ALT: 267
U/L, AST: $99 \mathrm{U} / \mathrm{L}$ ). During the course of the disease, these values regressed to the reference range without any additional treatment except intravenous hydration. Our patient is thrombocytopenic at the time of diagnosis and thrombocyte count is $75.700 / \mathrm{mm}^{3}$ In the continuation of the treatment, platelets have drawn a rising graph and reached the reference values within the first 3 days.

Informed Consent: Informed consent was taken both from the patient and his parents.

Peer-review: Externally peer-reviewed.

Author Contributions: Consept - DÖ, MK; Design - DÖ, MK, DT, SHT; Supervision - NS, AS; References - EÇ, MS; Data Collection and/or Interpretation - DÖ, MK, SHT; Analysis - DT, SHT, NS, AS; Literature Search - DÖ, DT, MK; Writing - DÖ, MK; Critical Review - NS, AS.

Conflict of Interest: The authors have not reported a conflict of interest.

Financial Disclosure: There is no financial support in this study.

\section{References}

1. http://www.who.int/mediacentre/factsheets/fs117/en/ Erişim tarihi: 02.01.2018

2. http://www.seyahatsagligi.gov.tr/Site/HastalikDetay/Dengue-Hummasi

3. Uyar Y, Aktaş E, Yağcı Çağlayık D, Ergönül Ö, Yüce A. Yurt dışı kaynaklı bir dengue ateşi olgusu ve literatürün gözden geçirilmesi. Mikrobiyol Bul 2013;47:173-80.

4. da Costa PS, Ribeiro GM, Junior CS, da Costa Campos L. Severe thrombotic events associated with dengue fever, Brazil. Am J Trop Med Hyg 2012;87:741-2.

5. Pereira LPLA, Brito MCA, Araruna FB, de Andrade MS, Moraes DFC, Borges $A C R$, et al. Molecular studies with Aedes (Stegomyia) aegypti (Linnaeus, 1762), mosquito transmitting the dengue virus. Parasitol Res 2017;116:2057-63.

6. Trung DT, Thao le TT, Hien TT, Hung NT, Vinh NN, Hien PT, et al. Liver involvement associated with dengue infection in adults in Vietnam. Am J Trop Med Hyg 2010;83:774-80.

7. Wills BA, Oragui EE, Stephens AC. Coagulation abnormalities in dengue hemorrhagic fever: serial Investigations in 167 vietnamese children with dengue shock syndrome. Clin Infect Dis 2002;35:277-85.

8. Martina $B E$, Koraka P, Osterhaus $A D$. Dengue virus pathogenesis: an integrated view. Clin Microbiol Rev 2009;22:564-81.

9. Krishnamurti C, Peat RA, Cutting MA, Rothwell SW. Platelet adhesion to dengue-2 virus-infected endothelial cells. Am J Trop Med Hyg 2002;66:435-41.

10. Mairuhu AT, Setiati TE, Koraka P, Hack CE, Leyte A, Faradz SM, et al. Increased PAl-1 plasma levels and risk of death from dengue: no association with the 4G/5G promoter polymorphism. Thromb J 2005;3:17.

11. Basu A, Chaturvedi UC. Vascular endothelium: the battlefield of dengue viruses. FEMS Immunol Med Microbiol 2008;53:287-99.

12. Dengue: guidelines for diagnosis, treatment, prevention and control. Geneva (Switzerland): World Health Organization; 2009. Figure 2.1: The course of dengue illness. p. 25. (http://whqlibdoc.who.int/ publications/2009/9789241547871_eng.pdf?ua=1 